\title{
Competitive Pressure and Business Performance in East Java Batik Industry
}

\author{
Noorlailie SOEWARNO ${ }^{1}$, Bambang TJAHJADI ${ }^{2}$, Devitania PERMATANADIA ${ }^{3}$
}

Received: September 01, 2020 Revised: October 26, 2020 Accepted: November 05, 2020

\begin{abstract}
This study aims to assess the impact of competitive pressure and innovation capability on business performance in small- and mediumsized enterprises (SMEs) in the batik industry in East Java, Indonesia. Furthermore, this study explores the impact of competitive pressure on business performance through innovation capability as a mediating variable. This research was quantitative using primary data with questionnaire as a method of sampling collection. The measurement of the variables was captured using Likert scale. The respondents were small- and medium-sized enterprises (SMEs) in the batik industry in East Java Province, Indonesia. The sample totaled 254 subjects. The data analysis was done using SEM-PLS. The results of the study show that: 1) there was a positive direct impact of competitive pressure on business performance; 2) competition pressure positively influences innovation capability; 3) innovation capability positively influences business performance; and 4) innovation capability has a partial mediating role in the effect of competitive pressures on business performance. The findings of this study suggest that managers in SME's batik industry should increase their effort to cope with the high competitive pressure to increase the innovation capability, so that they can have an advantage to face successfully competitors, leading to higher business performance.
\end{abstract}

Keywords: Competitive Pressure, Innovation Capability, Business Performance

JEL Classification Codes: D91, M41, M40, M21

\section{Introduction}

\subsection{Research Background}

This study aims to assess the impact of competitive pressure and innovation capability on business performance using innovation capability as a mediating variable in the batik

${ }^{1}$ First Author and Corresponding Author. Lecturer, Department of Accounting, Faculty of Economics and Business, Universitas Airlangga, Indonesia [Postal Address: Penjaringansari II G/24, Rungkut, Surabaya, East Java, 60297, Indonesia]

Email: noorlailie-s@feb.unair.ac.id

${ }^{2}$ Lecturer, Department of Accounting, Faculty of Economics and Business, Universitas Airlangga, Indonesia.

Email: bambang.tjahjadi@feb.unair.ac.id

${ }^{3}$ Department of Accounting, Faculty of Economics and Business, Universitas Airlangga, Indonesia.

Email: devitania.permatanadia-2016@feb.unair.ac.id

(c) Copyright: The Author(s)

This is an Open Access article distributed under the terms of the Creative Commons Attribution Non-Commercial License (https://creativecommons.org/licenses/by-nc/4.0/) which permits unrestricted non-commercial use, distribution, and reproduction in any medium, provided the original work is properly cited. industry in east Java Indonesia. UNESCO has recognized Indonesian batik, including it in the Representative List of the Intangible Cultural Heritage of Humanity. This world recognition is inseparable from the unique technique, symbols, philosophy, and role of written batik in the life of the Indonesian people from birth to death. This world recognition carries great responsibility for the Indonesian nation because it is obliged to preserve, develop, and protect written batik as a world-class national cultural product.

Business organizations need to have a performance measurement system as a tool to measure the action and effort of a manager; managers need to have the skills to improve performance in the organization and reduce failure (Madanchian \& Taherdoost, 2019; Vij \& Bedi, 2016). Therefore, performance measurement plays an important role in translating organizational strategies into outcomes (Kaplan $\&$ Norton, 2001). The purpose of holding the measurement is to dig up information about the state of the company's processes and products and enable the organization to learn from the past to improve its performance (González et al., 2010). To implement organizational management, a resourcebased view approach is important because it becomes the 
rationale for companies to be able to provide competitive advantage (Andersén, 2010). It is important to investigate how companies respond to competitive pressures when faced with a large number of competitors (Liu \& Atuahene-Gima, 2018; Tyler et al., 2018). Intense competition begins when a company introduces new products to the market to seize market opportunities or meet customer needs in a complex environment that will be a challenge for the company. This happens because the business environment has experienced changes marked by environmental uncertainty and increased intensity of competitive growth (Anning-Dorson, 2016; Liu \& Atuahene-Gima, 2018; Purnama \& Subroto, 2016). So, the company needs to investigate the sustainability of the company by observing its competitive position (Gomes et al., 2018).

Based on research from Schumpeter (1942), theoretical and empirical studies have explored the relationship of market competition between products and innovation. However, the existence of competitive pressures affecting company performance is an important issue. Often, different approaches produce inconsistent results. Tyler et al. (2018) said that SMEs respond differently to perceived competitive pressures, managers 'perceptions of competitive pressures affect managers' focus on competitive opportunities or competitive threats. Meanwhile, Purnama and Subroto (2016) argued that the impact of the intensity of competition was significantly positive on information technology investment, but the intensity of competition had a significant negative effect on business performance. Because of this inconsistency, the researchers added a mediating variable, namely, innovation capability. Innovation is the core of business strategy in the form of a process in connecting new ideas with processes and products/services that require organizations to learn from experience and achieve and maintain a competitive advantage in the market (Alinejad \& Anvari, 2016; Loewe \& Chen, 2007; Varadarajan, 2018). Innovation is increasingly recognized because it has an important contribution to organizational success, organizational performance, and survival, and creates competitive advantage for companies (Anning-Dorson, 2016; Baregheh et al., 2012). Because innovation varies greatly in nature, the main problem is how to get an innovation effort with a high chance of success (Baregheh et al., 2012; Loewe \& Chen, 2007).

Innovation is influenced by competitive pressures (RuizOrtega et al., 2016). Previous research has examined the relationship between competitive pressures and innovation. Distanont and Khongmalai (2018) said that innovation increases profits in competition through external factors. However, Ghosh et al., (2017) stated that intensified competition can reduce additional innovation. Innovation increases opportunities to improve company performance, encouraging companies to increase their tendency to succeed in the market (Anning-Dorson, 2016). Previous research has examined the relationship between innovation and business performance. Based on the research by Ulubeyli et al. (2018) posit that innovation based on competitive pressures could lead to company sustainability unless using a cost leadership strategy has no impact on the company's sustainability. However, Hamelink and Opdenakker (2019) suggest that business model innovation affects company performance.

This study differs from previous studies in terms of model and measurement modifications. Research by Purnama and Subroto (2016) uses an information technology investment mediation model in explaining the relationship between competitive pressures and performance. This study uses a mediating model of innovation capability in the relationship between the influence of competitive pressures and business performance. The variable capability of innovation is measured by organizational innovation, processes, products/services, marketing, and relationships. Also, this study modifies measurements. Purnama and Subroto (2016) measure the competition pressure variable with the amount of competition from similar companies, product competition, and market share competition. This research uses competition pressure variables measured by product competition, market share competition, similar companies, technological change, price competition, government regulations, and policies, as well as promotion and distribution channels. Purnama and Subroto (2016) measure business performance variables by increasing competitive advantage, increasing financial performance, increasing profitability, and increasing market share. This study uses business performance variables as measured by financial performance and non-financial performance that includes customers, internal business processes, growth and learning. This research will focus on SMEs in East Java.

The purpose of this study is to examine the mediation role of innovation on the influence of competitive pressures toward business performance in the SMEs of the batik industry in East Java. This research is expected to contribute to improving the performance of SMEs, especially SMEs in the batik industry so that they can improve their competitiveness by innovating in the current competitive era. Based on research by Schumpeter (1942), theoretical and empirical studies have explored the relationship of market competition between products and innovation. However, the existence of competitive pressures affecting company performance is an important issue. Often, different approaches produce inconsistent results. There are several previous studies that state that competitive pressures affect business performance. Tyler et al. (2018) said that SMEs respond differently to perceived competitive pressures, managers 'perceptions of competitive pressures affect managers' focus on competitive opportunities or competitive threats. Research by Alinejad and Anvari (2016) shows that the management process had a positive and significant effect on organizational performance due to mediating the role of competition intensity. 
However, there are previous studies that argue that competitive pressure is significantly negative on business performance. Research by Purnama and Subroto (2016) said that the impact of the intensity of competition was significantly positive on information technology investment, but the intensity of competition had a significant negative effect on business performance. Because of this inconsistency, the researchers added a mediating variable, namely, innovation capability.

\section{Literature Review}

Business performance is defined as a measure of levels of achievement of planned targets, such as achievement of production, costs, quality, delivery schedules, services, sales volume, market share, and profitability (Purnama \& Subroto, 2016). There are several factors affecting business performance such as competitive pressure (Tyler et al., 2018), innovation capability (Ulubeyli et al., 2018; Hoang \& Ngoc, 2019), social capital (Santosa et al., 2020), strategies (Kaplan \& Norton, 2001; An \& Kim, 2019), strategic management accounting (Phornlaphatrachakorn \& Na-Kalasindhu, 2020), budgetary goal characteristics (Le \& Nguyen, 2020), etc. Companies need to develop multi-dimensional performance such as a balanced scorecard (Choi et al., 2018). The balanced scorecard makes managers look at the business from four perspectives, namely, customer perspective, internal perspective, innovation and learning perspective, and financial perspective (Kaplan \& Norton, 1992).

Competitive pressure is defined as the level of competitive atmosphere in the industries in which the company's industry operates (Lertwongsatien \& Wongpinunwatana, 2003). The intensity of competition is defined as market factors that affect the level of competition measured by the number of similar companies in the same industry, product competition in the market, resulting in changes in market share from the competition, the level of price manipulation, contractual agreements between customers and competitors, changes in government regulations and policies, intensity price competition, competition product intensity (differentiation), product promotion, and channel distribution (Chong et al., 2005; Subroto, 2015). Organizations are likely to adopt innovation because of intense competition in a competitive environment (Pfeffer \& Leblebici, 1977). Organizations will distribute resources to offer innovative products or services to react to competitors in a competitive environment (Reich \& Benbasat, 1990). Innovation is the application of knowledge to produce new knowledge (Drucker, 2011). Innovation capability facilitates companies to implement appropriate process technology to develop new products to meet market needs and eliminate the threat of competitiveness (Adler \& Shenbar, 1990). Innovations are important for the sustainability of excellence (Johannessen et al., 1999).
Every new idea that generates added value by application in practice can be called innovation (Jon-Arild, 2013).

Businesses that operate in complex environments are a challenge for business leaders in adapting to changes in the environment (Anning-Dorson, 2016). Competition pressures affect business performance in various ways. The sharp nature of competition will be a serious problem for companies, this happens because the business environment has undergone a change marked by the uncertainty of the business environment and the intensity of increased competition growth (Purnama \& Subroto, 2016). Companies will try to survive the complexity of the environment through adaptation (Anning-Dorson, 2016). Some previous research that discusses the effect of competitive pressures on business performance is Tyler et al. (2018), Yu et al., (2017), and Alinejad and Anvari (2016). The research shows that competitive pressures affect business performance. Therefore, the following hypothesis is developed:

H1: Competition pressure affects the business performance of the batik industry SME in East Java

The pressure of competition affects innovation capability in various ways. Pressure from industry or competitors in the market is very strong in terms of developing new products for the market, continuous improvement of production processes, or even the introduction of new applications for technology (Distanont \& Khongmalai, 2018). Service innovation has become an inseparable element in ensuring competitive advantage (Chiu \& Yang, 2018). Some previous studies discussing the effect of competitive pressure on innovation capability are Ghosh et al. (2017), Younge and Tong (2018), Distanont and Khongmalai (2018), and Cornett et al., (2019). The research shows that competitive pressures affect innovation capability. If there is continued high competition among business industries of the same size, the opportunity for the development of innovations will be higher (Distanont \& Khongmalai, 2018). Therefore, the following hypothesis is developed:

H2: The pressure of competition affects the innovation ability of the SMEs in the batik industry in East Java

Innovation capability influences business performance in various ways. Innovation provides many advantages for companies to be able to face new challenges (Hadjimanolis \& Dickson, 2000). Innovation will strengthen the company's competitiveness because competition encourages companies to become more innovative (Anning-Dorson, 2016). To overcome high competition, companies will be motivated, not only to combine all improvements, but also to try to combine innovations to differentiate themselves from other companies ('Ruiz-Ortega et al., 2016). Some previous studies 
suggest that innovation ability positively related to business performance (Ulubeyli et al. (2018), Abbas \& Hassan (2017), Hamelink \& Opdenakker (2019), Hoang \& Ngoc (2019), and Oliveira et al. (2018)). The research shows that innovation capability influences business performance. Therefore, the following hypothesis is developed:

H3: Innovation Capability affects the business performance of the batik industry MSME in East Java

Market changes due to environmental complexity put pressure on businesses to adapt and be strategically oriented (Anning-Dorson, 2016). Due to competitive pressures, organizations must be involved in activities that will be carried out to produce high performance and competitive advantage. To respond to environmental demands and maintain and improve business performance, companies must adjust their intrinsic and extrinsic functions (Garcia-Zamora et al., 2013). So, to compete effectively over time, organizations must perform well in efficiency and innovation. Yu et al. (2017) say that an environmental innovation strategy mediates the full/partial relationship between environmental regulation/ stakeholder pressure and environmental performance. Therefore, the following hypothesis is developed:

H4: Innovation capability mediates the influence of competitive pressures on the business performance of the SME batik industry in East Java

\section{Research Methodology}

This research is classified as an explanatory quantitative research. Primary data is used in this study. The population of this research is all of UMKM Batik in East Java. The exact population cannot be known considering the frequency with which SMEs enter and exit the batik in the industry. A total of 245 Batik UMKM samples have been collected using the purposive sampling method. The data collected in this study utilizes a questionnaire based on indicators of competition pressure measurement, business performance, and innovation capability from SMEs in East Java. The Likert scale is used to measure all variables in this study. A 5-point scale is used to describe the level of agreement of respondents on the statements in the questionnaire. Competition pressure is measured using seven indicators, namely, product competition, market share competition, similar companies, technological change, price competition, government regulations and policies, as well as promotion and distribution channels (Chong et al., 2005; Purnama \& Subroto, 2016; Yang \& Meyer, 2015; Anning-Dorson, 201; Sahi et al., 2019; Karakasnaki, 2019). Measurement of business performance is using a balanced scorecard developed by to Kaplan and Norton (1992) to evaluate aspects of the company on four dimensions, namely, financial dimensions and non-financial dimensions that include customer perspectives, internal business processes, and learning and growth. Measurement of innovation ability uses indicators of organizational innovation, processes, products/services, marketing, and relationships (Martinez-Cones et al., 2017; Gupta, 2017; Rajapathirana \& Hui, 2018). Before being distributed, the questionnaire had passed a pilot test to 30 respondents and its validity and reliability was tested using SPSS 16.0. The validity test uses alpha 5\% with a Table R-value of 0.3610 . The reliability test used a Cronbach's Alpha value of 0.6 (Setbon \& Raude, 2010). This study using SEM PLS with WarpPLS 5.0 software to analyze data.

\section{Result and Discussion}

Outer model measurement is carried out to test the validity and reliability of three variables. In the first interaction, an outer model test is carried out to directly influence the competition pressure (CP) on business performance (BP). All loading factors lower than 0.7, namely, CP1, CP2, CP4, CP7, and $\mathrm{BP} 4$, and BP5, are removed. After that, we proceed with the outer model test for all variables including mediation variables innovation capability (IC). The convergent validity test shows that competition pressure, innovation ability, and business performance have average variance extracted (AVE) values of $0.601,0.515$, and 0.596 , respectively. Because the minimum AVE value is 0.5 and the loading factor limit is ideally at least 0.7 , the indicators IC2, IC5, and IC7 must be removed. In the third iteration, the results of the loading factor testing indicators measuring the variables of competition pressure, the ability of innovation, and business performance after eliminating IC2, IC5, and IC7 are all above 0.7. Convergent validity test shows that competition pressure, innovation ability, and business performance have the average variance extracted (AVE) values of $0.601,0.598$, and 0.596 , respectively. All variables meet the minimum AVE value of 0.5 .

As shown in Table 1, all indicators can be stated to meet the discriminant validity test because the value of 0.775 obtained by the competition pressure is greater than the value of its relationship with other variables. The value of 0.773 obtained for innovation capability is greater than the value of its relationship with other variables. The value of 0.772 obtained for business performance is greater than the value of its relationship with other variables. Therefore, all measurement indicators used are valid. The reliability test is done through a composite reliability test. The value of composite reliability for the variables of competition pressure, innovation ability, and business performance are $0.818,0.856$, and 0.936 , respectively. All variables meet the minimum composite reliability value of 0.7 . That is, the variables of competition pressure, innovation ability, and business performance are reliable. 
Table 1: Discriminant Validity Between Correlations

\begin{tabular}{|l|c|c|c|}
\hline & Competitive Pressure & Innovation Capability & Business Performance \\
\hline Competitive Pressure & 0,775 & 0,193 & 0,031 \\
\hline Innovation Capability & 0,193 & 0,773 & 0,590 \\
\hline Business Performance & 0,031 & 0,590 & 0,772 \\
\hline
\end{tabular}

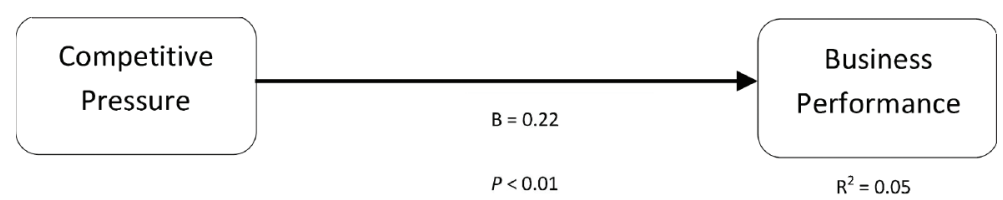

Figure 1: The Direct Effect of Competitive Pressure on Business Performance

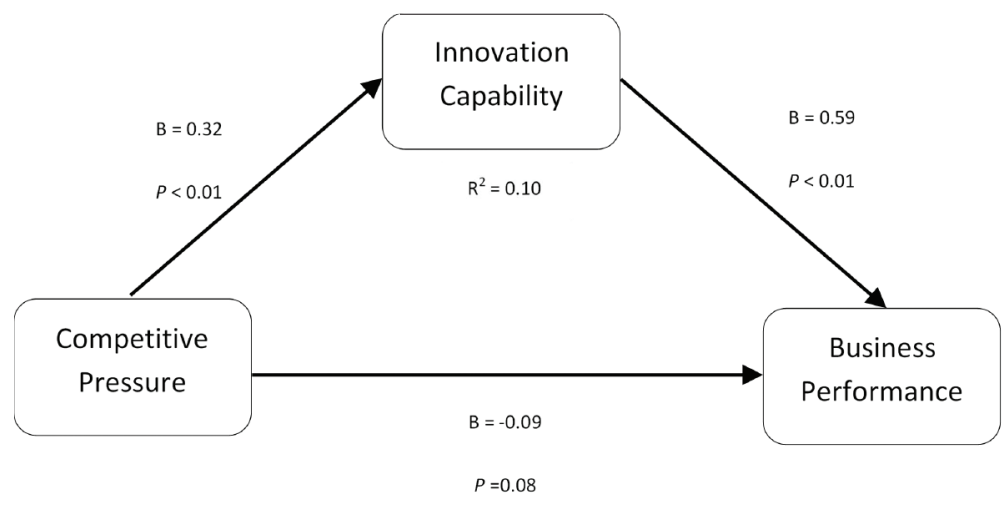

Figure 2: The indirect effect of Competitive Pressure on Business Performance with mediation

The inner model is used to test the structural model that has been prepared. By using WarpPLS 5.0, the results of testing the direct effect of competition pressure and performance before inserting the mediating variable can be described in Figure 1.

With a p-value of less than 0.01 and a regression coefficient $(B)$ of 0.22 , the figure shows that there is a significant positive relationship between competition pressures and business performance. Business performance has a coefficient of determination (R2) of 0.05 , which means that competitive pressures can predict business performance of $5 \%$. These results indicate that hypothesis 1, stating competitive pressures affect business performance at SMEs Batik in East Java, is supported.

Testing the effect of competitive pressure on business performance using the mediating variable of innovation capability is shown in Figure 2.

Figure 2 shows that competition pressure on business performance has a negative and significant relationship with a proven p-value equal to 0.08 and a regression coefficient (ß) of - 0.09 . Then, mediation can be carried out by including mediation variables in testing the indirect effect.
Testing the relationship between competition pressure and innovation ability produces p-values less than 0.01 and a regression coefficient ( $($ ) of 0.32 . That is, this indicates the existence of a positive and significant influence of competitive pressure on innovation capability. Thus, hypothesis 2, which says competition pressure affects innovation capability at SMEs in East Java, can be accepted. Innovation capability has a coefficient of determination (R2) of 0.10 , which means that competitive pressure can predict innovation capability by $10 \%$.

In this study, the analysis of the relationship of innovation ability on business performance produces a p-value of less than 0.01 and a regression coefficient ( $\beta$ ) of 0.59 . That is, this indicates there is a positive and significant influence on innovation capability on business performance so that hypothesis 3 can be accepted. Business performance has a coefficient of determination (R2) of 0.34 , which means innovation capability can predict business performance by $34 \%$.

The effect of mediating innovation capability in the relationship of competition pressure and business performance shows positive and significant results considering the two 
segments that make up the influence of competitive pressure on innovation capability and the effect of innovation ability on performance are both positive and significant. SEM-PLS analysis results also provide a p-value below $1 \%$ for indirect effects with two segments, so hypothesis 4 which states that innovation capability mediates the effect of competitive pressure on performance is shown to be significant, in this case, the effect of mediating innovation capability is partial considering that there is still a direct influence of competitive pressures on performance.

Determination of the strength of the level of mediation of innovation capability in indirect effects can also be done through the calculation of variance accounted for (VAF). If the VAF yield is less than $20 \%$, then there is no mediating effect. If the VAF value ranges from $20 \%$ to $80 \%$, it indicates partial mediation. And if the VAF is more than $80 \%$, it shows full mediation.

The VAF calculation result of $46.2 \%$ shows innovation capability to provide partial mediation in the influence of competitive pressures on business performance. This test shows that hypothesis 4, suggesting that innovation capability mediates the effect of competitive pressures on business performance at SMEs in East Java, is accepted.

This research confirms that there is a significant influence of competitive pressures on business performance. Thus, this study confirms previous research (Alinejad \& Anvari, 2016; Purnama \& Subroto, 2016; Yu et al., 2017; Tyler et al., 2018), which states that competitive pressures have an impact on business performance. Competitive pressure forces batik SMEs businesses to make adaptations to survive in a dynamic environment (Aning-Dorson, 2016) by continuing to try to fulfill the things that consumers want. The pressure of competition causes batik SMEs to try to find innovations such as designing new motifs or implementing new color compositions that adjust to the current trend.

Competitive pressure can increase innovation, and this is evident in this research. This confirms previous research (Distanont \& Khongmalai, 2018; Younge \& Tong, 2018; dan Cornett et al., 2019). High competition in the industry will make companies that cannot adapt to stay outside of the business. Competitive pressure will encourage companies to innovate such as developing new products/ services in the market, improving production processes, using new technologies or applications in the company's business processes, etc. (Distanont \& Khongmalai, 2018). The existence of this innovation will increase competitive advantage (Chiu \& Yang, 2018), so the company can win the competition in its industry and generate high enough profits so that business performance increases.

Innovation capability is proven to affect business performance. The results of this study are in line with the studies by Abbas and Hasan (2017), Oliveira et al. (2018), Ulubeyli et al. (2018), and Hamelink and Opdenakker (2019).
Innovation can strengthen a company's competitiveness (Anning-Dorson, 2016) and is a challenge for companies to increase profits (Hadjimanolis \& Dickson, 2000). In the written batik industry, the ability of batik SMEs to innovate, especially following the wishes of consumers, will make the company able to survive the highly competitive pressures and can increase profits earned by the company.

It is interesting that the direct effect of environmental pressure on performance that was initially positive before mediation turns negative after mediation. This shows that competitive pressures can directly trigger a spirit for SMEs to accept challenges, adapt, and improve business performance. However, after mediation, the direct effect of competition pressure becomes negative, which can be interpreted that competition pressure can also cause companies to innovate that represents costs and in the short term will have an impact on declining corporate profits, but in the long run innovation can improve performance. Through continuous innovation, SMEs can successfully face competition so that it can improve business performance. Thus, competitive pressures can increase business performance if mediated by innovation.

\section{Conclusions}

The results of the analysis and discussion show that managers in the batik industry need to pay attention to the competitive pressure within the industry and also increase innovation capability, so that the business performance will increase accordingly. Innovation capability is proven to have a mediating role in the relationship of competitive pressure toward business performance. Future studies could use different methods, for example using mixed methods or experimental methods to further sharpen the explanation of the causal effect of the role of moderation in innovation capability to influence the pressure of competition on business performance.

\section{References}

Abbas, M. W., \& Hassan, M. U. (2017). Moderating Impact of Environmental Turbulence on Relationship between Business Innovation and Business Performance. Pakistan Journal of Commerce and Social Sciences, 11(2), 575-596. DOI: 10.1051/ matecconf/20179001009

Adler, P. S., \& Shenbar, A. (1990). Adapting your technological base: The organizational challenge. Sloan management review, 32(1), 25-37.

Alinejad, S., \& Anvari, A. (2016). The Mediating Effect of Collaborative Structure and Competitive Intensity on the Relationship between Process Management and Organizational Performance. Iranian Journal of Management Studies, 12(1), 149-174. DOI: 10.22059/IJMS.2018.259810.673169 
An, H. J., \& Kim W. F. (2019). A Case Study on the Influence Factors of Financial Performance of Korean Automotive Parts Cooperation Companies through Research Hypothesis. Journal of Asian Finance, Economics and Business, 6(3), 327-337. https://doi.org/10.13106/jafeb.2019.vol6.no3.327

Andersén, J. (2010). Resource-based competitiveness: managerial implications of the resource-based view. Strategic Direction, 26(5), 3-5.

Anning-Dorson, T. (2016). Interactivity innovations, competitive intensity, customer demand and performance. International Journal of Quality and Service Sciences, 8(4), 536-554.

Baregheh, A., Rowley, J., Sambrook, S., \& Davies, D. (2012). Innovation in food sector SMEs. Journal of Small Business and Enterprise Development, 19(2), 300-321.

Chiu, C. N., \& Yang, C. L. (2018). Competitive advantage and simultaneous mutual influences between information technology adoption and service innovation: Moderating effects of environmental factors. Structural Change and Economic Dynamics, 49(C), 192-205.

Choi, S. B., Min, H., \& Joo, H.-Y. (2018). Examining the interrelationship among competitive market environments, green supply chain practices, and firm performance. The International Journal of Logistics Management, 29(3), 1025-1048.

Chong, V. K., Eggleton, I. R., \& Leong, M. K. (2005). The impact of market competition and budgetary participation on performance and job satisfaction: a research note. The British Accounting Review, 37(1), 115-133.

Cornett, M. M., Erhemjamts, O., \& Tehranian, H. (2019). Competitive environment and innovation intensity. Global Finance Journal, 41, 44-59.

Distanont, A., \& Khongmalai, O. (2018). The role of innovation in creating a competitive advantage. Kasetsart Journal of Social Sciences, 1-7.

Drucker, P. F. (2011). Post-Capitalist Society. New York, NY: Routledge.

Garcia-Zamora, E., Gonzalez-Benito, Ó., \& Munoz-Gallego, P. A. (2013). Organizational and environmental factors as moderators of the relationship between multidimensional innovation and performance. Innovation: Management, Policy \& Practice, 15(2), 224-244.

Ghosh, A., Kato, T., \& Morita, H. (2017). Incremental innovation and competitive pressure in the presence of discrete innovation,. Journal of Economic Behavior \& Organization, 135, 1-14.

Gomes, C. F., Najjar, M., \& Mahmoud M. Yasin. (2018). Exploring competitive strategic performance consistency in service organizations. Measuring Business Excellence, 22(2), 165-182.

González, L. S., Rubio, F. G., González, F. R., \& Velthuis, M. P. (2010). Measurement in business processes: a systematic review. Business Process Management Journal, 16(1), 114134.

Gupta, H. (2017). Integration of Quality and Innovation Practices for Global Sustainability: An Empirical Study of Indian SMEs. Global Business Review, 18(1), 210-225.
Hadjimanolis, A., \& Dickson, K. (2000). Innovation strategies of SMEs in Cyprus, a small developing country. International Small Business Journal, 18(4), 62-79.

Hamelink, M., \& Opdenakker, R. (2019). How business model innovation affects firm performance in the energy storage market. Renewable Energy, 131, 120-127.

Hoang, C. C., \& Ngoc, B. H. (2019). The Relationship between Innovation Capability and Firm's Performance in Electronic Companies, Vietnam. Journal of Asian Finance, Economics and Business, 6(3), 295-304. https://doi.org/10.13106/ jafeb.2019.vol6.no3.295

Johannessen, J.-A., Olsen, B., \& Olaisen, J. (1999). Aspects of innovation theory based on knowledge-management. International Journal of Information Management, 19, 121-139.

Jon-Arild, J. (2013). Innovation: a systemic perspective developing a systemic innovation theory. Kybernetes, 42(8), 1195-1217.

Kaplan, R. S., \& Norton, D. P. (1992). The Balanced Scorecard: Measures that Drive Performance. Harvard Business Review, 70(1) (January-February 1992), 71-79.

Kaplan, R. S., \& Norton, D. P. (2001). The Strategy Focused Organization: How Balanced Scorecard Companies Thrive in the New Business Environment. Boston, MA: Harvard Business School Press.

Karakasnaki, M., Psomas, E., \& Bouranta, N. (2019). The interrelationships among organizational culture and service quality under different levels of competitive intensity: An application in the shipping industry. International Journal of Quality and Service Sciences, 11(2), 217-234.

Le, T. N., \& Nguyen, D.D. (2020). An Impact of Budgetary Goal Characteristics on Performance: The Case of Vietnamese SMEs. Journal of Asian Finance, Economics and Business, 7(9), 363-370. https://doi.org/10.13106/jafeb.2020.vol7.no9.363

Lertwongsatien, C., \& Wongpinunwatana, N. (2003). E-commerce adoption in Thailand: an empirical study of small and medium enterprises (SMEs). Journal of Global Information Technology Management, 6(3), 67-83.

Liu, W., \& Atuahene-Gima, K. (2018). Enhancing product innovation performance in a dysfunctional competitive environment: The roles of competitive strategies and marketbased assets. Industrial Marketing Management, 73, 7-20.

Loewe, P., \& Chen, G. (2007). Changing your company's approach to innovation. Strategy \& Leadership, 35(6), 18-26.

Madanchian, M., \& Taherdoost, H. (2019). Assessment of Leadership Effectiveness Dimensions in Small \& Medium Enterprises (SMEs). Procedia Manufacturing, 32, 1035-1042.

Martinez-Conesa, I., Soto-Acosta, P., \& Palacios-Manzano, M. (2017). Corporate social responsibility and its effect on innovation and firm performance: An empirical research in SMEs. Journal of Cleaner Production, 142, 2374-2383.

Oliveira, J. A. S. d., Basso, L. F. C., Kimura, H., \& Sobreiro, V. A. (2018). Innovation and financial performance of companies 
doing business in Brazil. International Journal of Innovation Studies, 2, 153-164.

Pfeffer, J., \& Leblebici, H. (1977). Information technology and organizational structure. Pacific Sociological Review, 20(2), 241-261.

Phornlaphatrachakorn, K. \& Na-Kalasindhu, K. (2020). Strategic Management Accounting and Firm Performance: Evidence from Finance Businesses in Thailand. Journal of Asian Finance, Economics and Business, 7(8), 309-321. https://doi. org/10.13106/jafeb.2020.vol7.no8.309

Purnama, C., \& Subroto, W. T. (2016). Competition Intensity, Uncertainty Environmental on the use of Information Technology and its Impact on Business Performance Small and Medium Enterprises. International Review of Management and Marketing, 6, 984-992.

Rajapathirana, R. P. J., \& Hui, Y. (2018). Relationship between innovation capability, innovation type, and firm performance. Journal of Innovation \& Knowledge, 3, 44-55.

Reich, B. H., \& Benbasat, I. (1990). An empirical investigation of factors influencing the success of customer-oriented strategic systems. Information Systems Research, 1(3), 325-347.

'Ruiz-Ortega, M. J., Parra-Requena, G., \& Garcia-Villaverde, P. M. (2016). Do Territorial Agglomerations Still Provide Competitive Advantages? A Study of Social Capital, Innovation, and Knowledge. International Regional Science Review, 39(3), 259-290.

Sahi, G. K., Gupta, M. C., Cheng, T. C. E., \& Lonial, S. C. (2019). Relating entrepreneurial orientation with operational responsiveness: Roles of competitive intensity and technological turbulence. International Journal of Operations \& Production Management, 39(5), 739-766.

Santosa, M. G. S, Supartha, W. G., Riana, I. G. \& Surya, I. B. (2020). A Contiguity of Social Capital, Competence, and Business Performance Moderating by Government Policy. Journal of Asian Finance, Economics and Business, 7(9), 727-736.

Schumpeter, J. (1942). Capital, socialism, and democracy. London, UK: Allen and Unwin.
Setbon, M., \& Raude, J. (2010). Factors in vaccination intention against the pandemic influenza A/H1N1. European Journal of Public Health, 20(5), 490-494.

Subroto, W. T. (2015). Creative thinking development to foster economic creative: Evidence of state university of surabaya. International Review of Management and Marketing, 5(3), 108-113.

Tyler, B., Lahneman, B., Beukel, K., Cerrato, D., Minciullo, M., Spielmann, N., \& Cruz, A. D. (2018). SME Managers' Perceptions of Competitive Pressure and the Adoption of Environmental Practices in Fragmented Industries: A Multi-Country Study in the Wine Industry. Organization \& Environment, 1-27.

Ulubeyli, S., Kazaz, A., \& Sahin, S. (2018). Survival of construction SMEs in macroeconomic crises: Innovation-based competitive strategies. Journal of Engineering, Design and Technology, 16(4), 654-673.

Varadarajan, R. (2018). Innovation, Innovation Strategy, and Strategic Innovation. Innovation and Strategy, 143-166.

Vij, S., \& Bedi, H. S. (2016). Are subjective business performance measures justified? International Journal of Productivity and Performance Management, 65(5), 603-621.

Wright, P. M., Dunford, B. B., \& Snell, S. A. (2001). Human resources and the resource-based view of the firm. Journal of Management, 27, 701-721.

Yang, W., \& Meyer, K. E. (2015). Competitive dynamics in an emerging economy: Competitive pressures, resources, and the speed of action. Journal of Business Research, 68, 1176-1185.

Younge, K. A., \& Tong, T. W. (2018). Competitive pressure on the rate and scope of innovation. Journal of Economic Behavior and Organization, 150, 162-181.

Yu, W., Ramanathan, R., \& Nath, P. (2017). Environmental pressures and performance: An analysis of the roles of environmental innovation strategy and marketing capability. Technological Forecasting \& Social Change, 117, 160-169. 